\title{
Fabric-Rendered Identity: A Study of Dalit Representation in Pa. Ranjith's Attakathi, Madras and Kabali
}

Benson Rajan* and Shreya Venkatraman ${ }^{\dagger}$

\section{Abstract}

Cinema has played a role in caste politics in India. Its role ranges from special arrangement to consume the film to working in films based on caste based demarcated jobs. Films have always been in a constant struggle to eradicate eas well as to maintain the boundaries between the dominant and the dominated. Clothing is one such element which acts to represent the formation of a community's image in people's minds. The representation politics with the fabric worn in films becomes the clash between dress codes. These are symbolic conflicts played on the screen between social and cultural norms that possess the potential to alter identity and its structures of reality. This paper will be dealing with the analysis of three films by Pa. Ranjith: Attakathi (Cardboard Knife)(2012), Madras(2014) and Kabali(2016); to understand the representational politics involving the Dalit community with the help of costumes that the characters adorn in the films. Semiotics as an approach has been applied to understand the representation of Dalit identity reflected through clothing practices.

Keywords: Dalit Identity, Ambedkar, Blue, Caste Dress Code, Tamil Cinema, Mobility, Representation

* School of Business Studies and Social Sciences, Christ University Bengaluru, India; benson.rajan@christuniversity.in

† Christ University Bengaluru, India; shreya.raman@arts.christuniversity.in 


\section{Introduction}

One of Indian society's fundamental and most profound problems is caste. It was traditionally represented in the form of a structured hierarchical system of Varna. Films have constantly struggled to eradicate the boundaries between the dominated and the dominant. This ideological and material struggle has weakened governance systems but not caste (Racine \& Racine, 1998). Caste based films produced on the subject of Dalits and their struggles have given the downtrodden community visibility (Joshi, 2017). However, contemporary films are avoiding frontal confrontation of Dalit issues in lieu of entertainment value (Joshi, 2017). The representation of lower-castes in films, especially in the way that they are dressed and the clothing that they wear is significant with regard to their identification in the social order.

The word 'Dalit' has its origins in the Sanskrit word 'Dal', which means' to break' or 'broken and downtrodden' (Devakumar, 2007); the word 'Dalit' is also associated with 'scheduled castes' (SCs) in official state language. In Tamil Nadu, Dalits are referred to as the first Dravidians or Adi Dravidar (Racine \& Racine, 1998). The 'identity politics' in the state gave rise to political and social emancipation, embedded in Dravidian reform movements. Tamil cinema then became a platform to propagate Dravidian ideology during the Dravidian movement.

\subsection{Tamil Cinema and the Politics of Identity}

The representation in cinema is a portrayal of the existence of a 'being'. Derrida (Sweetman, 1999) saw the 'being' grounded in a perception of self, which is partially constructed by the social norm. This characterisation in Tamil Cinema is what Maritian (1962) refers to as the 'principal of identity'. The concept states that 'identity is not derived from the structure of the mind but from the structure of reality' (Sweetman, 1999). The 'structure of reality' created by the mind perceives the object according to its actual nature, barring any already constructed ideas of the object in focus (Sweetman, 1999).

Derrida's (Husserl, 1978) view on identity construction and the part that reality plays is seen in his idea of 'beings' and external 
environment (Sweetman, 1999). He also states that "all identities, presences, predictions, etc. depend for their existence on something outside themselves, something which is absent and different from them" (Critchlay \& Mooney, 1994, 462). "The outside" that Derrida (Husserl, 1978) describes constitutes the social and political aspirations of the Dalits and clothing became one of the material markers for emancipation, with an aspirational quality attached to them (Gupta, 2012). The fabric draped on a Dalit body is a contestation between empowered and disempowered representations in the struggle for social change. Educated Dalits in urban areas have learnt to associate certain kinds of clothing with manhood and emancipation (Gupta, 2012). The codes of clothing are closely tied to modernity and upward mobility for Dalits in the social hierarchy (Gupta, 2012). As Tarlo, (1996) points out, Indian dress codes were hence highly diversified according to caste, class, religion, occupation, education, region and politics (Tarlo, 1996).

The Adi Dravidians' fight for identity and self-respect in opposition to Brahminical traditions and political institutions came in the form of E.V. Ramaswami Naicker and his self-respect movement in 1925 (Racine \& Racine, 1998). These ideas of identity and respect were taken forward by Dravidar Kazhagam (Association of Dravidians), the political party formed by Naicker. The party eventually split, with C.N. Annadurai forming Dravida Munnetra Kazhagam (Association for the Emancipation of Dravidians) in 1949. DMK relied on cinema and efficient party organisation to mediate their socialist policies and language nationalism (Gorringe, 2011). Nonetheless, it was the entrance of the two film stars and future chief ministers of the southern state in the 1970s and 1980s in politics that made cinema a major player. M. G. Ramachandran and Jayalalitha's popularity in Tamil cinema was banked on by the All India Dravidar Anna Munnetra Kazhagam (AIADMK) in order to win the elections.

In terms of the Tamil film industry, it was only in the 1970s that the emergence of a genre of cinema dedicated to the realistic depiction of rural life on screen came about (Pandian, 2008). Some prominent films like Manam Oru Kurangu (The Heart is a Monkey) by Tamil playwright Cho. Ramaswamy, Kamal Hassan's Thevar Magan (Son 
of Thevar) in 1992, Kizhakku Chimaiyilee (In the Eastern Country) in 1993 heralded the rise of this particular genre.

This paper will be concerned with the analysis of three films by Pa. Ranjith: Attakathi (Cardboard Knife)(2012), Madras (2014) and Kabali[1](2016) in order to understand representational politics involving the Dalit community through the clothing that the characters wear in the films.

\section{Literature Review}

\subsection{Dalit Narratives and Religion}

The 'Dalit', according to Bharati (2002) is not a caste but an identity, which is constructed and yet a reality beyond denial. The National Commission for Scheduled Castes (2015) report for Tamil Nadu shows that the SCs population constitutes $20.01 \%$ of the total population. The commission passed a reservation policy of $18 \%$ for SC groups in Tamil Nadu to support the upliftment effort of the 76 SC groups in Tamil Nadu. Dr. B.R. Ambedkar saw the attainment of political rights through reservations and conversion to Buddhism as an ideological attack on untouchability against the dominant upper caste Hindus(Racine \& Racine, 1998).

There are two narratives on how untouchability emerged in Tamil Nadu. One group says that in the Sangam period it was based on birth (Subramaniam, 1966) whereas the other group contests this on the basis of occupational practices (Hanumanthan, 1979). The earliest mentions of Dalits can be found in the Tamil poem, Purananuru[1], which has a reference to Parayan (a term that denotes Scheduled castes in today's context).

Dr. B.R. Ambedkar unlike Mahatma Gandhi, never adhered to a religious and spiritual approach to attacking untouchability and always advocated for western democracy (Ganguly, 2002). The Bhakti Movement in the $8^{\text {th }}$ century sought to make the relationship between God and his followers personal. It was championed as a way around the caste hierarchy and the ritualistic prescription of the Brahmin priests. However, the movement did not dismantle the caste system. The 'untouchable' community of Vaishnava and 
Shaivite sect could approach God only after a purifying ordeal (Racine \& Racine, 1998). In this way, the Bhakti movement eventually became a part of the orthodox form of Hinduism (Racine \& Racine, 1998).

\subsection{Representation and the Dalit identity}

Butler (1990) saw representation as the 'normative function' of language as it either distorts or reveals the assumed truth. The language surrounding Dalit narratives has a normative function of identity that has been communicated on behalf of the Dalit population. This is visible with the underrepresentation of Dalits on media platforms (Balasubramaniam, 2011).

It is also one of many reasons behind the distortion of their issues. As Stuart Hall (1997) expresses, "representations sometimes call our very identities into question. We struggle over them because they matter and these are contests from which serious consequences can flow. They define what is 'normal', who belongs, and therefore, who is excluded" (p. 10). Therefore, we consider the collective representation which acts as a 'social fact' (Durkhiem, 1898) that is imposed on Dalits. The social fact is an oppressed lifestyle which makes the Dalit communities outcasts in Indian societies. This social fact is difficult to challenge as it is coercive and uniform in its effects (Durkhiem, 1898). The social fact of discrimination faced by Dalit communities generally obtains less representation in mainstream media as their experiences of inequality, prejudice and hostility from other dominant groups is a normative function of their social reality. For example, the Keelavenmani Massacre in 1968 was reported as a class issue in a local Tamil paper, Dinamani. Only when the issue was taken up by Dalit political parties such as Communist Party of India (Marxist), Puthiya Tamilagam (New Tamil Nadu)and Viduthalai Chiruthaigal Katchi (Liberation Panther Party) (Dharani, 2017), were the reasons of discrimination along caste-lines and untouchability brought to light (Balasubramaniam, 2011). The killings were instrumental in the making of Leftist films like Varumaiyin Niram Sivappu (the colour of poverty is red) in 1980 and Kann Sivanthal Mann Sivakkum (when the eyes turn red, the soil will too) in 1983 (Yamunan, 2016). 
The media frames or discourses are seen as discursive producers that define social fact and normative functions for its audience to apply in everyday life (Hancock \& Garner, 2011). Such representations lead to the categorisation of physical features and supports the generation of stigma. This was highlighted by Prem Singh (2011) in his analysis of Sujata, Lagaan and Swadesh. The repeated construction of the Dalit image as being dark-skinned and untidy created a stereotypical screen image for the community (Singh, 2011). Hence, frames can be seen as violently forming categories and discourses within which identities and its representations emerge (Hancock \& Garner, 2011).

Indirect relations established through cases of violence against Dalits in Tamil cinema highlights the problem of importance that visual media gives to the community. Dalit writer Stalin Rajangam is of the view that Kabali (2016) was a response to the Dharmapuri riots in 2012 (Yamunan, 2016). The eloping of a Vanniyar (a 'dominant' group of Other Backward Caste (OBC) in Southern India) woman and a Dalit man led to the riots which included villages being ransacked by Hindu mobs (Yamunan, 2016). As Balasubramaniam (2011) points out, inclusion of oppressed communities in the media is required to ensure unbiased and impartial media coverage of Dalit issues (Balasubramaniam, 2011).

\subsection{Cinema and its Role in Caste Politics}

The improvement in the economic backgrounds of Dalits due to upward financial mobility and landed rights has not improved their status as a community facing extreme discrimination. In contemporary times, Performing Arts and Cinema are often carrying out the indirect mechanism of maintaining the divide between Dalit and higher caste communities. For instance, the release of Kalidas[2] in 1931 as the first talkie in Tamil was received with much enthusiasm by the subaltern group but was despised by the elites (Pandian, 1996). It started with a demarcation between Therukoothu (folk street theatre) that was patronised by the lowerclass people, and Bharatnatyam and Carnatic music which was exclusive only to Brahmins. This exclusivity was challenged when Tamil cinema halls became the first performance centres to bring both the masses and the elites under the same roof (Sivathamby, 
1981). This was achieved through seating based on the purchasing power and not on caste rights (Sivathamby, 1981).

However, on film sets, there were discriminatory practices on the basis of skill, i.e. directing, camera and editing were reserved for the upper castes and the low-skill of acting was available among the lower castes (Devakumar, 2007). According to Baskaran (1981), cinema of the silent era was categorised as 'low culture' because it drew its artists from the despised universe of circus, company drama and wrestling. Their art was criticised on the basis that actresses such as Thavamani Devi, who was from Sri Lanka was said to encourage women from respectable families to join the industry (Pandian, 1996).

From the 1970s onward, cinema has been seen as propagating a language of ethics and moral values (Pandian, 2008). The protagonists were often seen to be questioning the existing notions of morality and the way it functions in society; they then reinforced the same moral structure and emphasized the degradation of society in its absence. This phase in Tamil Cinema was termed 'Cinema Kalam'(Age of Cinema) by the citizens of the Cumbum Valley (Pandian, 2008). Tamil Cinema at that time provided a utopian future for the rural population (Pandian, 2008). This was capitalised upon by the AIADMK who tapped into the celebrity cinema stardom of M G Ramachandran (MGR) and Jayalalitha to propel their party into power. A survey taken in 2011 still spoke of M G Ramachandran as a heroic figure of the 1990s (Gorringe, 2011). Pandian (1992) analysed the rhetoric of political speeches and observed that political speeches utilised 'popular song lyrics' in speech-making. It drew on references from MGR's heroism in films where he was showcased as the catalyst for the upliftment of the downtrodden. Such tactics helped to reinterpret and reinforce a Tamil cultural identity, which combined with the actor's screen image, emphasised the importance of 'honour' in Tamil life (Pandian, 1992). This idea of moral living and the aim of attaining honour were seen in films such as the 1961 hit Thirudathe (Do Not Steal) and in the narrative of Azhagi (Beautiful Lady) (2002), which insisted on virtuous living even in the face of impossible situations. Moreover, the virtuous in cinema generally adhered to a clothing code that was representative of their moral identities. 


\subsection{Clothing as a Mark of Identity}

Caricaturing western clothing and the meaning imbibed in the selection of fabric has been crucial in Dalit representation. Derrida (Sweetman, 1999) suggested that the elements related to identity representation do not really have a fixed meaning and are essentially constructs of the mind. Clothing and its encoded notions of modernity, education, and prosperity are constructs that govern the material veiling of the body. Clothing is an element which is an 'outside' representation that helps in the formation of a community's image, in the mind of the people. The ragged clothes worn by older generations of lower caste communities were either due to poverty or in order for them to appear submissive to the upper caste (Jaoul, 2006). According to Robert Ross, clothes are part of cultural politics by which nations are produced (Ross, 2008). In the case of India, the Swadeshi[2] movement with its anti-colonial nationalism sought to drape the population with Indian made khadi [3] clothing (Gupta, 2012). The Swadeshi khadi became a critical marker for national identity, which was popularised by Mahatma Gandhi(Bean,1989). The Dalit community, in accordance with the established normative function were marginalised from the Swadeshi movement and consequentially they in turn rejected the movement (Gupta, 2012). Their rejection of the Swadeshi movement was in part due to recognition of the empowering potential of western clothing (Chan 2000).It was also the Dalit community's attempt to rise above caste structures.

Such attempts are still prevalent with the lower castes' aspiring upward mobility within the caste hierarchy. This can be seen in their adoption of Brahminical rites, customs and beliefs in a process known as 'Sanskritization' (Srinivas, 1956). It includes the seeping down of cooking practices, clothing, jewellery, language and the way of life of Brahmins (Carroll, 1977). The practice of maintaining Brahmanical codes of clothing was represented in the 1992 hit Thevar Magan, where Kamal Hassan adopts the combination of a white shirt and veshti (a long loincloth worn by men in some parts of India), when he inherits his father's position. The transition in the shedding of the modern clothing to adopt traditional clothing is portrayed in a much dramatised scene to showcase power shifts and attempts at retaining one's caste identity. 
By examining clothing standards in India, one may observe that dress codes are at the centre of wider issues like modesty, honour and respect (Tarlo, 1996). Tarlo further adds that the clash between these codes are symbolic of the conflict between social and cultural norms. In Uttar Pradesh, conflicts arose based on objections by upper class youths against a neat shirt and trousers worn by Scheduled Caste students (Jaoul, 2006). Such opposition of clothing practices by Dalit communities shows their lack of agency over their choice of attire.

The problem of 'what to wear' is no more than just a mundane question that one encounters as part of daily life. It has come to representissues related to identification and communication. This paper researches clothing patterns of the Dalit community's as a reflection of their attempts towards social and cultural mobility. It analyses the cinema of $\mathrm{Pa}$. Ranjith to understand Dalit representation through clothes in Tamil Nadu.

\subsection{Research Question}

This is an explorative study that seeks to understand differences in clothing and its caste based representation in cinema. The works of the film director Pa. Ranjith were chosen due to his claim in the media that his films address caste inequalities. Therefore, the following research question will guide our enquiry:

How is Tamil Dalit identity reinforced through the clothing of male protagonists in three films (Attakathi, Madras and Kabali) directed by Pa. Ranjith?

\section{Methodology}

This paper has utilised semiotics as an approach to understand the representation of Dalit identity reflected through clothing practices in Attakathi, Madras and Kabali. Saussure's (1915) semiotic analysis has been applied in studying representation of Dalits in Tamil cinema. The comparative structural analysis draws on Oberhardt's (2001) work on the portrayal of art museums in Hollywood cinemas. She used binaries to illustrate the common characteristics shared by real art museums and art museums portrayed in cinema (Oberhardt, 2001). Drawing on Oberhardt's (2001) use of cinematic 
frames to analyse the portrayals of museums in cinema, this study has employed frame analysis as a technique to examine Dalit representations through clothing.

Frame analysis consists of the selection of frames that present and emphasise the idea of 'what exists, what happens and what matters'(Scheff, 2005). The central concept of frame analysis is what Goffman (1974) calls 'key'. A 'key' is a set of conventions whose universal meaning is altered into something different by the participant (Scheff, 2005; Jameson, 1976). This study has taken four frames from each film on the basis of identity and caste meanings attached to clothes.

However, the meaning behind the codes of clothing and its interpretations has relied on the framework proposed by Roland Barthes (1968) for semiotic analysis. The framework analysis signs on the basis of the signifier and the signified from the Saussurean perspective (Bouzida, 2014). Barthes (1968) found that images hold significance in terms of the signs that recipients are able to connote through their cultural and symbolic backgrounds. The signs in a visual text can be interpreted in two levels of significance: denotative and connotative (Barthes, 1968). Denotation excludes all subjective meanings and refers to the literal meaning of the signs; connotation refers to culturally constructed ideas and meanings that the signs contain (Barthes, 1968). Here, connotation is a system comprising signifiers, signified and the process which unites the former to the latter (signification) (Bouzida, 2014). This framework according to Saussurean (1915) analysis maybe grounded in synchronic and diachronic analysis. In synchronic analysis, the events occur at the same time (Monaco, 2000). The researcher has to focus on a pattern of paired oppositions as a paradigmatic structure (Berger, 2011). This study has employed a paradigmatic approach to analyse the frames. Paradigmatic analysis requires a search for hidden patterns of opposition that are hidden in the text (Berger, 2011). This is discovered through the categorisation of signs under their denotative and connotative meanings. Based on the methodological precedents set by researchers above, this paper has categorised signs from the four frames of Pa. Ranjith's films into their denotative and connotative components. The focus of the categorisation was on various clothing patterns and their role in the 
representation of caste. Paradigmatic aesthetics of the montage of frames with similar connotations were further divided into subthemes, which are as follows:

\subsection{Analysis}

The history of deprivation for the Dalit communities from wearing clean, new clothes is partly founded in identifying codes of clothing. Caste as an identifying symbol required the Dalits to represent symbols of untouchability on their person (Tarlo, 1996). Dressing well, or wearing white coloured clothes has always been associated with the upper-caste. The Dalit communities are traditionally deprived from looking clean and being well-dressed. The films by $\mathrm{Pa}$. Ranjith draw on this representation by emphasising Ambedkar's suit and its connotative meaning for the Dalit communities.

\subsection{Ambedkar and the three-piece suit}

Dalit culture does not subscribe to the authenticity of Swadeshi clothes. Instead, they found power in 'foreign' clothes in order to mobilise their position in the unequal system of caste (Gupta, 2012). This is exemplified in the scene in which Rajinikanth's character is introduced in Kabali; there he dons a three-piece suit while stepping out of jail following 25 years of imprisonment.

This imprisonment was closely associated with the caste-based oppression that Dalit communities face. Kabali's three-piece suit symbolises liberation and prosperity that has transformed the Dalits from being identified as dirty and filthy according to caste rules of clothing. It is also possible to a pre-colonial Indian view of how clothes could transmit spirit and substance (Bayly, 1986).Hence, clothes are said to retain the very essence of the person who wears them and are perceived to have 'transformative' and 'moral' powers (Tarlo, 1996). These transformative powers are visible through Ambedkar's dressing in a three-piece suit, which is often viewed by Dalits as a means to escape from caste hierarchies (Guha, 2002).

In one scene, Rajinikanth's character also refers to the politics between Ambedkar's suit and Gandhi's loin clothes. The signification of such frames connoted Gandhi's opposition to 
western attire. He saw it as a symbol of colonial oppression. Gandhi's politics of non-cooperation against the British captured the popular imagination in the early 1900's (Gupta, 2012). His rejection of western clothing was symbolic of firm nationalism in pursuit of India's independence. Therefore, boycotting foreign clothing was a global statement renouncing a foreign power's governance of India. The Swadeshi Attire Movement for Gandhi was a celebration of self-governance through the spinning-wheel of liberating khadi fabric. It was also Gandhi's struggle to dewesternise himself and the nation. Therefore, we find Gandhi's loin cloth to be a symbol of sacrificing his position and his upper caste background (Guha, 2002).

In contrast, the Dalit community saw the loin cloth as a symbol of Brahminical oppression and an imposed occupational attire for menial tasks. Therefore, Gandhian attire did not provide any upward mobility for the Dalits. However, Ambedkar's blue suit and red tie shone as a mark of education, respectability and upward mobility in the socio-economic conditions of the Dalit population (Jaoul, 2006).

Clothes play a significant role in communicating messages (Hoffman, 1984) and Dr. Ambedkar's dressing in western attire had come under fire for not being 'culturally authentic' and 'unfit for a leader representing the poor' (Jaoul, 2006). However, Ambedkar was not representing the poor he was representing the untouchable Dalits. His attire was a political statement against the clothing hierarchy as he sought to break caste barriers that even imposed restrictions on clothing for Dalits (Tarlo, 1996). As the film's narration goes on, it shows the upliftment of Kabali and represents the same through clothing which signifies Ambedkar's drive for self-representation beyond the caste consensus. Kabaliin the movie was portrayed as an indentured labourer, who along with his wife works in a plantation in Malaysia. He eventually becomes a gang leader fighting for the rights of other workers. This transformation from Kabali being in the periphery to rising up as a saviour imitates the life of Dr. Ambedkar who became the voice of Dalits. As the film progresses, we see Kabali's clothing pattern change: from shiny patterned shirts to a more sophisticated suit. The inspiration behind the change is shown through Kabali's mentor 
and his appearance during public addresses that he delivers wearing a suit. The frame shows the leader in a dark blue suit and a red tie addressing a rally of suppressed communities. The combination of clothes is very similar to the portrayal of Ambedkar by the Dalit community and in mainstream media. This frame also clearly signifies the association drawn by Pa. Ranjith between Kabali and Dr. Ambedkar. The three-piece suit in which Ambedkar has captured the popular imagination was primarily blue in colour. The dominant association of this colour within the Dalit consciousness is portrayed by Pa. Ranjith in his three films.

\subsection{Blue as the dominant color}

Attakathi, Madras and Kabali have at least one frame dedicated to showing the colour blue as the sign and clothes as the signifier. This colour is seen as an important paradigm in the explicit representation of Dalit empowerment in films. In Madras, one frame depicts the lead characters clad in blue coloured clothes, teaching in a school opened for the children in their community. Kabali also has a similar frame in which the colour of the uniform of a school meant for adolescents with a criminal past is blue. The third film, Attakathi, has the lead character being introduced in a blue shirt, signifying an educated youth from a backward community. Blue as a colour is often used by Dalit communities especially in protests and rallies as a mark of empowerment. A frame in Madras, has the local football team clad in blue and the opposition team clad in red.

Therefore, we find Ambedkarites' identifying this blue colour with Dalit consciousness. This culturally symbolic colour has been used as a tactic for identifying Dalit children in schools. The Shiv Sena and Bharatiya Janata Party Alliance in Maharashtra enforced apolicy in 1995 to dress Dalit children in blue uniforms (Guru, 2005). The colour in this case contains a sense of cultural exclusion. Nonetheless, it also emerged as a self-identifying sign for Mahar Dalits in Maharashtra. Ambedkar is known to have introduced the blue Mahar's Flag as his party flag for the Independent Labour Party (Jaffrelot, 2005). It is representative of identifying with Dalit consciousness that is non-discriminatory. It also appeals to the masses as in the 'blue collar workers'. In all the three movies' 
frames the blue colour is associated with representation of the working class as well as working for them i.e. the masses. Blue signifies liberty and it is constantly compared to the blue sky. Mahayana Buddhism elaborates on the association of the colour blue with the sky and the notion of enlightenment (Hoeppe, 2007). Therefore, as it is popularly stated 'under the blue sky everyone is believed to be equal' we find a non-discriminatory association with blue. The blue uniform at a school meant for adolescents with a criminal past in Kabali showcased an egalitarian inclusivity that overlooks a problematic past. Further, the association of blue with education is constantly evoked in the films. This is drawing on the enlightenment, like the Buddha, and its potential to liberate the masses from their oppressive realities. Enlightenment is also a victory over ignorance that should bring forth mobility from caste restriction. It was also the colour of Ambedkar's party, signifying egalitarian enlightenment in order to uplift the masses whose pasts have restrained their progress in a democratic society. Therefore, clothes are representative of changing personalities and characteristics of individuals and their community.

\subsection{Politics behind higher caste dress code}

In the three films, the clothing of the political leaders is portrayed in contrast with the clothing codes followed by other characters in them. In Kabali, for instance, the transition of the characters of Kabali and Tony Lee (the antagonist) can be discussed through clothes. From wearing a shirt and trousers, both the characters change their style to wearing designer suits. Whereas, in Madras, a higher caste is indicated through the clothing of political leaders. The opening frame of the film introduces members of the two affluent parties in the state wearing a white shirt with a veshti or trousers. One of the frames shows 'Maari,' an aspiring politician from a backward community donning a white shirt when he is accepted by the leaders as one of them. Prior to his leadership role, he is seen wearing colourful shirts. However, after becoming the party leader his clothing style changes and he is seen only wearing white shirts in public. The white shirt has certain caste based signification. The lower castes in places like Travancore were prohibited from wearing white (Tarlo, 1996). Moreover, due to the practical difficulties of lower caste occupations including field 
labourers, crematorium workers and butchers, the colour white was not a practical colour for them to wear. Nevertheless, white clothes signify purity and sacrifice of luxurious pleasure (khadi). Leadership is always spotted with this colour as white clothing creates an illusion that the leadership is untarnished and clean, both literally and figuratively. Therefore, leadership in pursuit of trust and power from the people are generally seen dressed in white.

Contrary to this pattern, Attakathi sees a reversal of clothing codes. The lead character, Dinakaran, discards his simplistic combination of clothing and opts for a more rugged and colourful style when he gets involved in violent political life. Dinakaran starts wearing loose opened shirts and ties a cloth around his hand to portray a menacing image. Such dressing is also associated with the uneducated lower castes. They are depicted as dressing up in bright, garish and showy colours. This dressing style draws attention to them more in terms of comic relief than in any other light. Dressing in such a rugged, dark, and flamboyant manner enhances an individual's low personality traits and immodest characteristics. This representation through clothing styles is also used to portray henchmen on the cinematic screen. Their clothing often makes an indirect reference to lower castes and its association with a lifestyle of ridicule and violence. Films that emphasis castebased pride (Komban[4], Thevar Magan, Chinna Gounder[5]and Nattamai[6]) are known to portray the lower-caste as ridiculous savages. The clothing of individuals in signifiers of punk hairstyles and modern clothing do not posses agency in the social order portrayed in the films. However, actors dressing in a crisp white shirt and veshti are signifiers of inherited caste power. In contrast, we find Kabali is a protagonist wearing suits and wielding guns. His character is conscious of the power of dressing and in a noteworthy dialogue states that dressing in suits is his mark of dissent against the caste powers. Pa. Ranjith provides symbolic references to Dalit aspiration through simple and sophisticated dressing.

This approach to clothing is portrayed in Attakathi, Kabali and Madras as a mark of education and respect. This is evident in Madras, where the lead character is the only person in his 
community who has a stable job in an Information Technology company (IT). In one of the frames, the character is mocked for his clothing, correlating it with the idea that he is superior to the people of his community. In a society where parallels between different social classes are evident, clothing is a minute aspect in depicting hierarchy. Individuals who don western attire in the manner of trousers and shirts are often considered to be more educated than their traditionally attired counterparts. When the protagonist in the movie "Madras" is mocked for his clothing choice (an attempt to blend in with his new surroundings and elevated social standing), it reinforces the idea that any effort to break-free from the social pecking order is met with resistance from all communities.

This power struggle around clothing is still evident in contemporary times. The youth of the Dalit community are often seen carrying off uniform clothing codes such as 'wearing jeans and sunglasses'. This manner of dressing is perceived as a problem by Pattali Makkal Katchi (PMK) founder S.Ramadoss (Yamunan, 2016). He propagated this as being the reason behind young men and women defying caste hierarchies. This reference to clothing was made to justify the Dharmapuri riots that broke out in 2012 after a Dalit man and a Vanniyar woman eloped. Pa. Ranjith successfully depicts the undertones of this incident in Attakathi, Kabali and Madras. Dinakaran in Attakathi is seen as a man who loves the idea of being in love and changes his style of dressing according to the girl he is pursuing.

\section{Conclusion}

Dalit cinema in India has played the role of empowerment as well as been a resource for the establishment of the community's identity. In doing so, the filmmakers have often reinforced the notions and identity markers related to the Dalit community. This reinforcement stagnates their attempt to move beyond the established standards and markers of Dalit identity. Clothing has always played a huge role in prophesying the ideology of a community. Dress codes have been used by the upper caste and class to maintain their position in the hierarchy. Patterns of clothing 
also become a part of aspiration goals like career roles that make mobilisation in caste ranks a vital need. The director of the three films, Pa. Ranjith uses several identity markers in the context of colour, historical context, and recent acts of crime against the Dalit community other than clothing to portray the deep rooted protocols that are still associated with each caste. The clothing especially signifies the need to uphold differences in caste. Clothing is perceived to be an important part of an identity as it is shaped in accordance with the status that is appointed by society to a particular dress code. The symbolic role of clothes presents emancipation and empowerment for Dalits as a part of their struggle for liberation. The clothes represent a modernised phenomenon in the films, which is symbolic of a movement away from ancient traditions towards a modern casteless society. The dressing style here is apolitical statement inspiring clothing choices and performance of political resistance in Indian films. A Dalit dressed in a blue coloured suit is making an assertion of power to break the caste barrier in a society that has historically prohibited his expression through clothing. These oppressive rules governed Dalit bodies and were thus, symbolic of their caste status.

Films have often been seen as a means of escapism for downtrodden communities. Popular for its cheap entertainment value, Tamil cinema is well-received due to its reinforcement of ideas of patriarchy and caste-violence in society. With directors such as Pa. Ranjith using film as a medium to change mindsets along castes lines, it may be assumed that films and the fabric representation in them are being used to create a wave of change among social classes. This is being achieved through the portrayal of common community issues and the overcoming of the issues by relatable protagonists and their symbolic attires. Clothes and their representation have expressed the levels of condemnation that a community may experience. Clothes have also acted as tools for fighting this oppression and promoting the right to selfdetermination and freedom of expression.

\section{End Notes}

[1] Kabali is the protagonist's name.

[2] A Tamil poetic work in the Ettutokai (Eight Anthologies). 
[3] Kalidas is a biographical film made in Tamil about the Sanskrit poet Kalidas.

[4] A national movement promoting the wearing of clothing that was made in India from indigenous material produced in India.

[5] Khadi is an Indian home spun cotton which is used in making fabric for clothing.

[6] Komban is the protagonist's name.

[7] Chinna Gounder: Junior Gounder (Gounder is a title or surname used by the Vellalar community in Tamil Nadu).

[8] Nattamai is a reference to the Village Chief.

\section{References}

Balasubramaniam, J. (2011). Dalits and a Lack of Diversity in the Newsroom. Economic and Political Weekly, 46(11), 21-23. Retrieved from http:/ / www.jstor.org/stable/41151964

Barthes, R. (1968). Elements of Semiology. New York: Hill and Wang.

Baskaran, S. T. (1981). The Message Bearers: The Nationalist Politics and the Entertainment Media in South India 1880-1945. Madras: Cre-A.

Bayly, C. A. (1986). The Origins of Swadeshi (Home Industry): Cloth and Indian Society, 1700-1930. In A. Appadurai (Ed.). The Social Life of Things: Commodities in Cultural

Bean, S.(1989). Gandhi and Khadi, the Fabric of Indian Independence. In A. B. Weiner and J. Schneider (Ed.), Cloth and Human Experience (pp. 355-376), London: Smithsonian Institute Press.

Berger, A. A. (2011), Media Analysis Techniques. California: Sage Publication.

Bharati, R. S. (2002). 'Dalit': A Term Asserting Unity. Economic and Political Weekly, 37(42), 4339-4340. Retrieved from http:// www.jstor.org/ stable/4412748.

Bhatia, S. (2016). It's Time for the Comrades to think Red, Blue and Green Too. The Wire. Retrieved from:https://thewire.in/25531/its-time-forthe-comrades-to-think-red-blue-and-green-too/

Bouzida, F. (2014). The Semiology Analysis in Media Studies: Roland Barthes Approach. Retrieved from: http:// www.ocerint.org/ Socioint14_ebook/papers/293.pdf

Butler, J. (1990). Gender Trouble: Feminism and the Subversion of Identity. London: Routledge.

Carroll, L. (1977). Sanskritization, Westernization, and Social Mobility: A Reappraisal of the Relevance of Anthropological Concepts to the 
Social Historian of Modern India. Journal of Anthropological Research,33(4), 355-371.

Chan, A. (2000). Fashioning Change: Nationalism, Colonialism, and Modernity in Hong Kong. Postcolonial Studies, 3(3), 293-309.

Critchlay, S., \& Mooney, T. (1994), Deconstruction and Derrida. In R. Kearney (Ed.), Continental Philosophy in the 20th Century,(Vols. 8)(pp. 365-391). London: Routledge.

Devakumar, J. (2007). Caste Clashes and Dalits Rights Violations in Tamil Nadu. Social Scientist, 35(11/12), 39-54. Retrieved from http:// www.jstor.org/stable/27644251

Dharani, T. (2017, September 21). How the Dalit discourse is playing out in Tamil Nadu, 48 years after Keezhvenmani. Live Mint. Retrieved fromhttp://www.livemint.com/Politics/DQ9xqDBUL30bAblsOr7gL K/48-years-after-Keezhvenmani-how-the-Dalit-discourse-is-play.html

Dinakaran, N. (1957). Mudukulathar Kalavaram. Madurai: Dinakaran Publishers.

Durkheim, E. (1898). Representations indivuelles et representations collectives. Revue de Metaphysique et de Morale, 6, 273-302.

Gamson, W.A. (1990). The strategy of social protest, Belmont: Wadsworth Publishing.

Ganguly, D. (2002). History's Implosions: A Benjaminian Reading of Ambedkar. Journal of Narrative Theory, 32(3), 326-347. Retrieved from http:/ / www.jstor.org/stable/30224586

Goffman, E. (1974). Frame Analysis. New York: Harper Colophon Books.

Gorringe, H. (2011). Party Political Panthers: Hegemonic Tamil Politics and the Dalit Challenge. South Asia Multidisciplinary Academic Journal. Retrieved from http://samaj.revues.org/3224

Guha, R. (2002, December 8). The darling of the dispossessed. TheHindu. Retrieved fromhttp:// www.thehindu.com/ thehindu/ mag/ 2002/ 12/08/stories/2002120800580300.htm.

Gupta, C. (2012). 'Fashioning' Swadeshi. Economic and Political Weekly,47(42), 76-84.

Guru, G. (2005). Citizenship in Exile: A Dalit Case. In R. Bhargav and H. Reifeild (Ed.), Civil Society, Public Sphere and Citizenship: Dialogues and Perceptions (pp. 260-277). New Delhi: Sage Publications.

Hall, S. (1997). Representation: Cultural Representations and Signifying Practices. London: Sage. 
Hancock, B., \& Garner, R. (2011). Towards a Philosophy of Containment: Reading Goffman in the 21st Century. The American Sociologist, 42(4), 316-340. Retrieved from http://www.jstor.org/stable/41485719

Hanumanthan, R. K. (1979). Untouchability: An Historical Study Up to 1500 A.D. Madurai: Koodal Publishers.

Hoeppe, G. (2007). Why the Sky is blue: Discovering the Color of Life (J. Stewart, Trans.). Princeton: Princeton University Press.

Hoffman, J. H. (1984). How clothes communicate. Media Development, 31(4), 7-11.

Husserl, E. (1978). Origin of Geometry: An Introduction by Jacques Derrida (J.P. Leavey, trans.). Pittsburgh: Duquesne University Press.

Jaffrelot, C. (2005). Dr Ambedkar and Untouchability: Analysing and Fighting Caste. New Delhi: Permanent Black.

Jameson, F. (1976). On Goffman's Frame Analysis. Theory and Society, 3(1), 119-133. Retrieved fromhttp://www.jstor.org/stable/656942

Jaoul, N. (2006). Learning the use of symbolic means: Dalits, Ambedkar statues and the state in Uttar Pradesh. Contribution to Indian Sociology, 40 (2), 175-207.

Joshi, N. (2017, January 23). New voices but not enough noise. The Hindu. Retrieved from http://www.thehindu.com/opinion/op-ed/Newvoices-but-not-enough-noise/article14015881.ece

Maritian, J. (1962). A preface to Metaphysics. New York: Mentor.

Monaco, J. (2000). How to Read a Film: The World of Movies, Media, and Multimedia: Language, History, Theory. Retrieved from: https://books.google.co.in/books/about/How_to_Read_a_Film.html ?id=TSSfJb011QgC\&redir_esc=y

National Commission for Scheduled Caste. (2015). Annual Report 2010-11 $\mathcal{E}$ 2011-12. New Delhi: National Commission for Scheduled Caste. Retrieved from http://ncsc.nic.in/files/TN\%20minutes.pd

Oberhardt, S. (2001). Looking Through Frame 3: The Art Museum in Popular Film. Counterpoints, 167, 71-118. Retrieved fromhttp:// www.jstor.org/stable/42976615

Pandian, A. (2008). Cinema in the Countryside: Popular Tamil film and the remaking of rural life. In V. Selvaraj (Ed.). Tamil Cinema: The Cultural Politics of India's Other Film Industry. (pp.124-138). New York: Routledge.

Pandian, M. (1996). Tamil Cultural Elites and Cinema: Outline of an Argument. Economic and Political Weekly,31(15), 950-955. Retrieved fromhttp://www.jstor.org/stable/4404028 
Pandian, M.S.S. (1992). The Image Trap. New Delhi: Sage Publications.

Perspective, (pp. 285-321). Cambridge: Cambridge University Press.

Racine, Jean-Luc \& Josiane Racine. (1998). Dalit Identities and the Dialectics of Oppression and Emancipation in a Changing India: The Tamil Case and Beyond. Comparative Studies of South Asia, Africa and The Middle East, 18(1), 5-20.

Ross, B. R.(2008). Clothing: A Global History or, The Imperialists' New Clothes. Cambridge: Polity Press.

Saussure, D. F. (1915). Course in general linguistics, 2nd edition, New York: Hill Book Company.

Scheff, T. (2005). The Structure of Context: Deciphering "Frame Analysis" Sociological Theory,23(4), 368-385. Retrieved from http:/ / www.jstor.org/stable/4148887

Singh, P. (2011). The Representation of the Dalit Body in Popular Hindi Cinema. Unpublished manuscript, Department of Hindi, University of Delhi, Delhi, India. Retrieved from https:// www.academia.edu/ 25943972/The_Representation_of_the_Dalit_Body_in_Popular_Hindi Cinema

Sivathamby, K. (1981). The Tamil Film as a Medium of Political Communication. Madras: New Century Book House.

Srinivas, M. (1956). A Note on Sanskritization and Westernization. The Far Eastern Quarterly, 15(4), 481-496.

Subramaniam, N. (1966). Sangam Polity. Delhi: Asia Publishing House.

Sweetman, B. (1999). Postmodernism, Derrida and Diffe'rance: A critique. International Philosophical Quarterly, 39(1), 5-18.

Tarlo, E. (1996). Clothing Matters: Dress and Identity in India. London: C.Hurst and Co. Publishers.

Yamunan, S. (2016, July 31).'Kabali' film is a response to the 2012 Dharmapuri caste riots, says Dalit scholar Stalin Rajangam. The Scroll. Retreived from: https://thereel.scroll.in/812882/kabali-film-is-aresponse-to-the-2012-dharmapuri-caste-riots-says-dalit-scholar-stalinrajangam 